\title{
A Linguistic Study of Borrowings from English to Urdu
}

\author{
Dr. Muhammad Aslam Sipra (Corresponding author) \\ JCC, King Abdulaziz University \\ PO Box 80283, Jeddah 21589 Saudi Arabia \\ Tel: 966-509042190 E-mail: aslamsipra@yahoo.com
}

Received: 03-10- 2012

doi:10.7575/ijalel.v.2n.1p.203
Accepted: 02-11- 2012

Published: 01-01- 2013

\begin{abstract}
This paper discusses how English came into contact with Urdu language. Moreover, it outlines factors involved in borrowing from English to Urdu. It substantiates the influence of English on Urdu and demonstrates the conscious and unconscious shift of vocabulary items from one language to another during the interaction between speakers speaking different languages under any circumstances. The present study also unravels how people came across English in the Sub-continent. Pre-partition and post partition attitude of the people of the subcontinent towards English and the influence of English on Urdu are also bespoken.
\end{abstract}

Keywords: Language, borrowing, influence, English, loan words, Urdu, contact

\section{Introduction}

Unlike some other languages, English itself has been an insatiable borrower as described by David Crystal (2010) but today's English is a major donor language, a prime source of loaning for many other languages of the world. Likewise, Urdu is under the influence of English and borrowing many words and expressions from English same as more than 120 languages contributed towards the present vocabulary of English. The simplest kind of influence that one language may exert on another is the borrowing of words. When there is cultural borrowing, there is always the likelihood that the associated words may be borrowed, too (Edward Sapir, 1921). The term 'borrowing' refers to the adoption of individual words or even large sets of vocabulary items from another language or dialect (Hock, 1986).

There are around 7000 languages spoken all over the world. It has been found that when languages come into contact, there is transfer of linguistic items from one language to another due to the borrowing of words (Kachru, 1989). According to Kachru, there are essentially two hypotheses about the motivations for the lexical borrowing in languages. One is termed as the 'deficit hypotheses' and the other is the 'dominance hypothesis'. The deficit hypothesis presupposes that borrowing entails linguistic gaps in a language and the prime motivation for borrowing is to remedy the linguistic deficit, especially in the lexical resources of a language (Kachru, 1994).

Pakistan is a multilingual country where many languages are spoken as mother tongue. According to Rahman (2006), the power and authority is captured by two languages - English and Urdu. English, being the language of colonizers of the recent past, is the symbol of power, authority, manner and sophistication. Urdu is the second powerful language. On the other hand, indigenous languages are being neglected by the political quarters and are being devoured by the powerful languages. Urdu being national language serves as the lingua franca. It is the medium of instruction.

The constitution of Pakistan restricts the use of English but interestingly the constitution itself and the laws are written in English. English happens to be the language of privileged class in Pakistan that is why English borrowings are always welcomed. English is a second language in Pakistan. Using English as a second language predominantly derives from postcolonial countries where English was retained after independence (Schneider, 2007).

The world is changing day by day; American policies have no more support from the world. Western policies about Muslim countries have created a kind of disliking about English world. If we conduct a survey about the popularity of Europe in the country, the popularity rate would be very low but surprisingly it has no effect on English language; it is still regarded as a global language and gaining popularity day by day.

\section{Short History of Urdu}

Urdu as an oriental language has history of a few hundred years. Historically, it belongs to the Indo-European language. It appears to be quite acceptable that during the Mughal rule in India the word Urdu was used for Lashkar (Army). In Turkish, the word Urdu is used for army even now. During the process of its growth Urdu underwent many influences. During the twelfth century the Indian court was dominated by the Turkish courtiers. So the earlier form of Urdu underwent the Turkish influence to some extent but it was not that much strong. The languages affecting Urdu deeply were Arabic, Persian, Sanskrit, Hindi, and Punjabi. All these were the most developed languages of their times. Among them, Persian proved to be the greatest influential language on Urdu. 
The earliest writings which could be called Urdu rather than Hindi were the writings of Ameer Khusroo from 1255 A.D to 1325 A.D. He referred to his Urdu preface of Diwan as Hindi. The other book was written by Syed Mubarak, a disciple of Hazrat Nizam-ud-Din Aoliya, in which a quotation by Baba Ganj Shakkar is written in Urdu. From the thirteenth century Hindi is mentioned as the language of the region but Punjabi, Multani, Gujrati, Dakkani were referred to local names for distinction. Urdu came into being with the mixture of all such dialects but its original shape developed in Delhi and its surrounding area. All provinces still have their languages but the language of U.P was Hindi which is now known as Urdu.

Until the rule of Jahangir (a Muslim ruler), the word Urdu does not seem to be in use. However, Rekhta alongside Hindi appears to be taking shape. It was a mixture of many dialects, i.e. Hindi, Persian, Arabic etc. Rekhta became popular in Deccan before it reached Delhi which is reflected in Mir's writings. Rekhta remained in use upto Mirza Ghalib's age. From the seventeenth century the word Urdu came into use for the language but in a limited sphere. By the end of eighteenth century the poets and writers called Urdu as the language of Delhi. After independence, Urdu became the national language of Pakistan. However it doesn't mean that it is restricted to this country only. It is the mother tongue of the people of some of the provinces of India and is easily understood in almost all the countries of South Asia.

\section{3-Influence of English on Urdu of Pre-Partition India}

The British not only captured the Indian throne but they had also established their colonies in majority of the world. They were powerful politically and technically and they had no rival. It was during the golden age of Europe when great progress in the field of science and technology was made. It was the time during which English was developing rapidly. Soon it achieved the status of a language which was fully equipped in order to face the challenges of the rapidly changing world. This is the reason why it has attained the glory of the international language. However, despite being the language of the rulers, it could not influence Urdu before partition of India for certain reasons. Firstly, Urdu was not the national language of the Indian Sub-continent. It was a language spoken in a particular region and by a particular religious sect i.e., the Muslims. The Muslims were certainly not a majority. Hence, being a minority language it did not come face to face with English. Secondly, the Muslims were the rulers of India before the British and it was they who were robbed of power. Hence, they hated not only the British but their language also. This is the reason why they stopped getting the education whose medium was English. Thirdly, the Muslim majority areas were kept ignorant in order to push them to the basest level of the society. Fourthly, the Muslims tried to keep their language Urdu free from corruption.

\section{English as an International Language}

In the early twentieth century, English appeared to be the international language. It was adopted as either an official or a second language by a considerable number of countries. In twentieth century, it even reached the areas where it was not before. By the end of the twentieth century, it became an international language because it had a cosmopolitan vocabulary, inflectional simplicity and natural gender. More than half of the world's technical and scientific periodicals are published in English. It is a widely spoken and written language in the world. No language has ever enjoyed such widespread popularity. One can say that this is the truly global language.

English is an international language spoken in many countries both as a native and as a second or foreign language. It is taught in schools in almost every country on this earth. It is a living and vibrant language spoken by over 300 million people as their native language. Millions or more speak it as an additional language. English is spoken habitually in the United States, the British Isles, Ireland, Canada, Australia, New Zealand, the Republic of South Africa, Liberia, and many territories under the United Kingdom and the United States of America. It is estimated that 300 million people speak English as a second language, and an additional 100 million people use it fluently as a foreign language. Approximately 1000 million or one billion people around the world have some knowledge of English either as a native language, as a second language, or as a foreign language. (M.S Thirumalai, 2002).

English is the language of new technology, of computers, software and the internet (Crystal, 2003). So we have no substitute in the field of high-tech communication and the internet; the travel business etc. Languages change naturally and borrowing some expressions from other languages is not a big deal as they are often needed to describe things more directly. But people should know the need to use English correctly.

\section{Different Assumptions about Borrowing}

People in Pakistan have different opinions about this phenomenon. Some of them assume that it's only a matter of globalization or they presume that every language is changing and this is part of it. That's why many of those don't care at all. But there are some people who are meticulous and worried over the rapid fire of English words on their mother tongue. They want to protect their language from the invasion of English as they consider language as a part of their culture and identity. They are concerned that the Urdu language seems to be replaced by some kind of mixed language. Young people grow up with mixture of two languages (Urdu and English).They even don't have alternatives of many words in their mother tongue. In young generation, code mixing and code switching has become a part of their speech but older people have affiliation with their language and they feel uncomfortable with such situation.

\section{How Urdu encountered English}

Urdu encountered English when the British came to India. The relationship between the sub-continent and the British started in the beginning of seventeenth century when East India Company was established in the sub-continent with its much broader vision and long term goals to rule the sub-continent so they had the entire India in view. 
When the British came to India, both English and Urdu were influenced by each other. In the later years, Muslim empire became very weak. The Mughal Empire collapsed owing to its own inefficiency, internal strife, uprising of the antiMuslim forces and the criminal negligence to develop the naval forces and strengthening of rule in the coastal areas. On the other hand, the East India Company had full backing of their government and people in all respects. The British government constantly gave their financial support; sent competent rulers and advisors to achieve their goal of bringing the sub-continent under their rule. Hence in 1858 A.D., the British government made India its colony.

As far as the contact of English and Urdu is concerned, it can be traced in three stages:

1. At first, the British tourists started coming to the sub-continent, both languages started influencing each other in a very limited way, the words were mostly the names of goods brought and sailed by the merchants of both the nations.

2. The second stage is the beginning of the seventeenth century when the company gained strong influence over the local politics. During this period words entered Urdu language were related to politics along with the words from trade.

3. The third stage is the beginning of the eighteenth century when the British tried to oust the Dutch, the French and the Portuguese from the sub-continent. They started English as a medium of education which influenced Urdu even with more force.

After 1857, particularly the transference of the English words into Urdu was faster. After the War of Independence 1857, the British occupied India and became enemy of the Muslims of the sub-continent. The British considered The Muslims responsible for the rebellion against them but virtually all it was because of the Hindu's conspiracies. The British imposed English on the people by replacing Persian completely. English replaced Persian in all the fields including education. Urdu was given lower status as it belonged to the common man. The Muslims did not like it first as they considered Urdu their identity. In the earliest decades of the twentieth century, the Hindus gave rise to Urdu-Hindi controversy. It was the time when Muslims of India realized that they should have a country of their own in which they could speak their language and practice their religion. This period ranges from end of eighteenth century until now. This is time of massive transference of English words to Urdu and it has not stopped yet. This rapid transference is still going on. In countries where English is a second language, the range and depth of its function is more than a foreign language as English becomes integral to the workings of a country ( D'Souza, 2001).

\section{Variations in the Process of Borrowing}

Borrowing can be in different ways:

1. It can be direct borrowing with a little change and even without any change in the original word

2. The second way is as translator of the word which is already available in the vernacular

3. The third is the mixture of local and foreign language.

Mostly borrowing takes place from the dominating to the subordinate. The present article is concerned with the first above mentioned way of borrowing. When a language takes words from another language, it tries to adopt them with the help of the sounds closest to the original sounds of the word it possesses. Urdu is a language of rich sounds. So it borrowed many words in their original form. For example machine, lens, image, state, cell, physician, blood etc. However, this does not mean that the English words did not undergo any change. Somehow or the other, they underwent some changes. The borrowing of foreign words always entails their phonetic modification. There are sure to be foreign sounds or accentual peculiarities that do not fit the native phonetic habits. They are then so changed as to do as little violence as possible to these habits. Frequently, we have phonetic compromises (Edward Sapir, 1921). Table 1 shows the examples of words which underwent some changes after borrowing.

Table 1. Examples of Words Showing Variations after Borrowings

\begin{tabular}{|c|c|c|c|}
\hline English words & English Transcription & Urdu Transcription & Phonemic Variation \\
\hline ambulance & |'æmbjələns| & |'æmbplens| & /jə/ is replaced by /p/ \\
\hline antenna & |æn'tenə| & |æn'tı:nə| & /e/ is replaced by /I:/ \\
\hline art & $|a: t|$ & |a:rt| & $\mathrm{r}$ is clearly pronounced \\
\hline café & |'kæfeI| & |'kæfeI| & $\mathrm{k}$ is unaspirated \\
\hline cast & |ka:st| & |ka:st| & no change except unaspirated $\mathrm{k}$ \\
\hline chair & $\left|\mathrm{t} \int \mathrm{e} \partial\right|$ & $\mid \mathrm{t}$ feər $\mid$ & $\mathrm{r}$ is pronounced at the end \\
\hline Christmas & |'krisməs| & |'krismis| & $\begin{array}{l}/ \mathrm{\partial} / \text { is replaced by } / \mathrm{I} / \text { and } \mathrm{k} \text { is } \\
\text { also unaspirated }\end{array}$ \\
\hline column & |'kpləm| & |'kplım| & $/$ /a/is replaced by $/ \Lambda /$ \\
\hline double & $|' \mathrm{~d} \Lambda \mathrm{bl}|$ & $|' \mathrm{~d} \Lambda \mathrm{b} \Lambda \mathrm{l}|$ & $/ \Lambda /$ is articulated between $b$ and 1 \\
\hline engine & |'endzin| & |'IndzIn| & /e/ is replaced by /I/ \\
\hline glamour & |'glæmə| & |'glæmər| & $/ \mathrm{r} /$ is pronounced \\
\hline honour & 'pnə| & |'pnər| & $/ \mathrm{r} /$ is pronounced \\
\hline journalist & |'d33:nəlist| & |'dzrnəlist| & $/ 3: /$ is replaced by $/ \mathrm{r} /$ \\
\hline medicine & |'medsn| & |'medis $\Lambda \mathrm{n} \mid$ & $/ \mathrm{I} /$ and $/ \Lambda /$ are pronounced \\
\hline
\end{tabular}




\begin{tabular}{|c|c|c|c|}
\hline wrong & $|\mathrm{rng}|$ & $|\mathrm{rpy}|$ & $\mathrm{g} /$ is prominent at the end \\
\hline radio & |'reidiəひ| & |'rædiəu| & diphdhong is replaced by /æ/ \\
\hline report & |ri'po:t| & |ri'po:rt| & $\mathrm{r}$ is pronounced \\
\hline tank & $\mid$ tæyk $\mid$ & $\mid$ tæyk & $/ \mathrm{t} /$ is unaspirated \\
\hline travel & |'trævḷ| & |'træv $\Lambda$ l| & $\begin{array}{l}\text { unaspirated } t \text { and } / \Lambda / \text { is } \\
\text { articulated in the final syllable }\end{array}$ \\
\hline
\end{tabular}

In Urdu, aspirated sounds are unaspirated, $\mathrm{r}$ is pronounced clearly, diphthongs are replaced by monophthongs, /a/ is replaced by $/ \mathrm{N} /, \mathrm{N} / \mathrm{N}$ is replaced by $/ \mathrm{\partial} /$,sometimes stress patterns are different which results in different pronunciation.

Countless words entered Urdu from English which are transliterated. The fact is that despite having equivalents in Urdu, people are unaware of these equivalents (see Table 2).

Table 2. Transliterated Words

\begin{tabular}{llllllll}
\hline computer & heater & motorcycle & dictionary & camera & phone & cricket & government \\
\hline refrigerator & air freshner & hanger & syllabus & photo & mobile & engine & editor \\
\hline vacuum cleaner & air conditioner & diaper & laptop & school & pencil & glass & media \\
\hline cycle & perfume & switch & report & college & pen & operation & world cup \\
\hline television & programme & microphone & dryer & gas & bag & police & receiver \\
\hline cell & image & radio & charger & antenna & station & sofa & scheme
\end{tabular}

The present study delineates that loan words are mostly nouns and frequently used in Urdu language. This is also observed that there are some nouns in English which describe relations, i.e. uncle, aunt, grandmother, grandfather. In English, there is only one word for father's brother, mother's brother, husband of mother's sister but in Urdu we use the word mamu /ma:mu:/ for mother's brother, chacha /t $\mathrm{fa}: \mathrm{t} \mathrm{a} /$ for father's younger brother, taya /ta:ja/ for father's elder brother, khala /kha:la/ for mother's sister and khaloo /kha:lu/ for khala's husband. In English, the word grandfather is used both for mother's and father's father but in Urdu the situation is different as nana /na:no/ is used for mother's father and the word used for father's father is dada/ða:ðə/. Young generation from educated class feels more comfortable with English terms instead of Urdu. So the English nouns describing relations are also very popular in Pakistan.

\section{Contributing Factors towards Borrowings}

\subsection{Government Policies}

In countries where English is a second language, the range and depth of its function is more than a foreign language as English becomes integral to the workings of a country (D'Souza, 2001). After independence of Pakistan the influence of Arabic and Persian was almost finished as the government retained English as the second language of the country. Government introduced bilingualism in educational field. It was the time when Urdu began accepting the influence of a language which was fully equipped, modern and was also the language of their rulers in the past. Government policies have always been English-friendly in Pakistan. There have been two streams of education in terms of language since independence i.e. Urdu and English. Both are used side by side. Even now, two medium are existing in almost every field of life. So, English words entered Urdu without any obstacle. With the passage of time, frequency of borrowing words increased so much that Urdu seems to lose its ground in Pakistan. Countless English words and expressions have entered Urdu and most of them even don't have their equivalents in Urdu.

\subsection{Media}

Media has contributed a lot in this respect as it facilitates flow of English words into Urdu language. Urdu today does not contain the English nouns only but adjectives, verbs and adverbs, too. Almost everybody who has excess to electronic media is bilingual. It is the language of business. The information stored in computers is mostly in English. English is used in world's sports and the entertainment programmes. It is the language of the five of the largest broad casting companies of the world (BBC, CNN, NBC, CBS, CBC). English entertaining programmers are very popular among them; they like them and copy them. Today Urdu has a rich mixture of English borrowings in it.

\subsection{Social Consciousness}

According to the Albert C. Bough (2010) “.........he is likely to make an effort to adopt the standards of grammar and pronunciation of the people with whom he has become identified......"

English has become the second language in the countries like Pakistan, India, Kenya, Singapore and Nigeria. It is used as a foreign language in many countries like Holland, Senegal etc. This is quite surprising that in education sector of Pakistan, we hardly find pure Urdu speakers. Students are unable to complete their conversation without the help of borrowings. People use code mixing for status symbol. They try to speak English with their children. Some young children are grown up with English as their mother tongue; they speak L1(Urdu) in English accent.

\subsection{Opinion Makers}

The elite class in Pakistan reckons that English is a modern language and the prime language of knowledge to access to 
international market and communication. It would be a reverse gear as it were if it was replaced by a vernacular. Our own language brings orthodoxy and limits our scope and vision. Translations into Urdu are even more difficult than English and are understood by even fewer people. Especially children and young people find it easier to use English (Harris Khalique, 2006).

\section{Conclusion}

English in the latter half of the twentieth century has induced Urdu very much. That is why it has become nearly impossible to count English words in Urdu. The process of borrowing is still going on. In fact, elite class has craze for English as they have direct contact with it. They go abroad for higher studies and even to spend their holidays. They catch the English language while staying abroad. When they return they use it fully or by mixing it in Urdu. This has some advantages and disadvantages, too. Urdu enriched its vocabulary by borrowing a treasure of words. Secondly, Urdu was a complex language before, but when Urdu started borrowing English Words, it underwent the process of simplification. This simplification enabled Urdu language to cope with the new situation which was necessary to retain the interest of the speakers. English is a language which borrowed words from many other languages like French, Latin, Greek, Arabic etc. This way, Urdu established contact with the world through English. However, when a language borrows too many words from another language, it is in the danger of being corrupted because when the loan words penetrate into a language massively, their standard cannot be tested. In the same way, Urdu has borrowed many words of English that it has become almost impossible to maintain the standard. Hence, great many words from vulgar speech have become part of Urdu. It has become a toy in the hands of a child. People misuse it as they insert as many English words as they like. So the standard has lost. A patriotic speaker finds it very difficult to adopt too many words from English whose equivalents are already present in Urdu and they are merely replaced because English has become a language of Fashion today. Urdu did not borrow words according to its own word-structure and fixed standard which resulted in the loss of its respect globally. It is very painful for its speakers as their pride in their language shatters and their self confidence is lost.

\section{References}

Bough, A.C. \& Cable, T. (2010). A history of the English language (5 ${ }^{\text {th }}$ ed.). Abingdon: Routledge Crystal, D. (2003). English as a global language. Cambridge: Cambridge University Press.

Crystal, D. (2010). The Cambridge Encyclopedia of Language. Cambridge: Cambridge University Press.

Hock, H, H. (1986). Principles of historical linguistics. New York: Mouton de Gruyter.

Jean, D.S. (2001). Conceptualizing range and depth in Indian English. World Englishes, 20(2), 145-159.

Kachru, B. B.(1986). The Alchemy of English: The Spread Functions and models of Non-native Englishes. Oxford: Pergamon Press.

Kachru, Y. \& Nelson, C. L. (2006). World Englishes in Asian context. Aberdeen: Hong Kong University Press

Kachru, B.B. (1994). The speaking tree: A medium of plural canons. In Georgetown Round Table in Languages and Linguistics (GURT). Washington, D.C.: Georgetown University Press.

Khalique, H. (2006). The Urdu - English relationship and its impact on Pakistan's social development. Paper presented at Workshop titled Between state ideology and popular culture: Urdu literature and Urdu media in contemporary Pakistan, Held in Heidelberg, Germany, 20-22 July 2006.

Sapir, E. (1921). Language: An introduction to the study of speech. New York: Harcourt, Brace

Schneider, E. W. (2007). Postcolonial English_Varieties around the World. Cambridge: Cambridge University Press.

Thirumalai, M.S. (2002). Introduction to TESOL: Retrieved December 24, 2012 from

http://www.languageinindia.com/april2002/tesolbook.html 